\title{
Analysis of evaluations performed by undergraduate nursing alumni: a Brazilian multicenter study*
}

\author{
Avaliação de egressos de cursos de graduação em enfermagem: estudo brasileiro multicêntrico \\ Evaluación de egresados de carreras de grado en enfermería: estudio brasileño multicéntrico
}

How to cite this article:

Aguiar KLA, Vieira MA, De Domenico EBL. Analysis of evaluations performed by undergraduate nursing alumni: a Brazilian multicenter study. Rev Esc Enferm USP. 2021;55:e20200084. DOI: https://doi.org/10.1590/1980-220X-REEUSP-2020-0084

\section{Katiuscia Larsen de Abreu Aguiar ${ }^{1}$ \\ Maria Aparecida Vieira ${ }^{2}$ \\ Edvane Birelo Lopes De Domenico 3}

* Extracted from the thesis "Validação Externa do Instrumento de validação de Egressos de Enfermagem IAE-ENF: Estudo multicêntrico. Universidade Federal de São Paulo, 2019.

${ }^{1}$ Universidade Federal do Acre, Centro de Ciências da Saúde e do Desporto, Rio Branco, AC, Brazil.

${ }^{2}$ Universidade Estadual de Montes Claros,

Departamento de Enfermagem, Montes Claros, MG, Brazil.

${ }^{3}$ Universidade Federal de São Paulo, Escola Paulista de Enfermagem, Departamento de Enfermagem Clínica e Cirúrgica, São Paulo, SP, Brazil.

\begin{abstract}
Objective: To compare evaluations performed by undergraduate nursing alumni in three dimensions: sociodemographic characterization, identification and insertion into the job market, and professional training evaluation. Methods: Cross-sectional, quantitative, and multicenter study with alumni of three Brazilian public institutions. Data analysis was carried out according to the internal reliability of the used instrument and by applying descriptive statistics. Results: The participants were 446 alumni who obtained their degrees from 2013 to 2016. Most were women, white (44\%) or brown (38\%), and were between 25 and 30 years old. Most had a specialization degree or were studying to obtain one (54\%), had a paid occupation (89\%), and were employed by a single institution (60\%), with the care area prevailing $(57 \%)$ in the sample. High levels of satisfaction were found among alumni of two institutions in the evaluation of content learning and essential experiences for training, whereas the other institution obtained better evaluations regarding professional practice. Conclusion: The profile of academic experiences, graduate education, and entry into the job market varied according to the evaluated institution. The findings favored critical-reflective analysis of the institutions' pedagogical projects.
\end{abstract}

\section{DESCRIPTORS}

Nursing Assessment; Multicenter Study; Education, Nursing. 


\section{INTRODUCTION}

Course evaluation, as a continuous process of reflection and action, brings dynamism to the organizational reality by orienting institutional objectives and polishing social pertinence and professionalism of undergraduate education. Following the professional trajectory of alumni is a fundamental aspect for higher education institutions (HEIs) to assess the efficacy of their role and having the possibility of reconsidering it, so policies and strategies oriented toward improving education quality are implemented and, therefore, society's needs are met ${ }^{(1)}$.

The Brazilian Ministry of Education issued a document with a critical-reflective analysis about the role of higher education in Brazil and the world covering the period between 2003 and 2025. This document emphasized that education is, above all, a public asset and the main vector of social inclusion. The balance between what is essential to citizenship and social inclusion and mobility and what is strategic for the country must be guaranteed, but also set against the undergraduate education characterized by low quality ${ }^{(2)}$.

Professional undergraduate training in Brazil follows guidelines, put into force from the turn of the 21st century onwards and which orient the creation of courses and ensure values, from the perspective of both intentionalities of higher education and the profession itself. The 2001 Brazilian National Nursing Curriculum Guidelines (DCN/ENF, as per their abbreviation in Portuguese) provide resources for formulating and evaluating undergraduate nursing course pedagogical projects $(\mathrm{UCPP})^{(3)}$. Since their establishment, DCN/ENF also favored the development of instruments to evaluate alumni, a fundamental step for critical analysis of UCPP regarding the ability to keep the balance between its intentionalities and professional practice scenarios ${ }^{(4)}$. The commitment of higher education in health to meet the demands of the Brazilian Unified Health System (SUS), which is free and universal, is a constant concern in studies addressing nursing alumni. The goal is that HEIs actively participate in the full execution of SUS regarding fulfillment of its social role, so imbalances between supply and demand, regional inequities, and primary healthcare intellectual impoverishment, among other disservices that low quality in higher education can originate, are prevented ${ }^{(4-5)}$.

In this scenario of concerns, the following questions emerged: How is professional training according to the view of undergraduate nursing course alumni of three Brazilian public institutions in three different Brazilian states, which were chosen as the setting of the present study? What is the level of satisfaction of these alumni with their professional training and the practice of their profession?

The objective of the present study was comparing the evaluations performed by undergraduate nursing course alumni of different educational institutions in three dimensions: sociodemographic characterization, identification and insertion into the job market, and professional training evaluation.

\section{METHODS}

\section{Study Type}

Cross-sectional, quantitative, and multicenter study.

\section{Population and Selection Criteria}

The selected study locations were three undergraduate nursing courses that are part of Brazilian public universities: Federal University of Acre, referred to as HEI-1; Montes Claros State University, referred to as HEI-2; and Federal University of São Paulo, referred to as HEI-3. The legal representatives of these HEIs consented to the execution of the present study, including the disclosure of the institutions' social identities, by signing agreement letters.

Selection of these HEIs was based on the fact that they are geographically and socially different. The first is located in the North Region of Brazil (city of Rio Branco, state of Acre), whose economy relies on extractive activities and agribusiness and whose population is markedly miscegenated. The second is located in Montes Claros, in the north of Minas Gerais state, an area that stands out for its agriculture and livestock, industrial, and service provision activities. The third, located in the city of São Paulo, is in the main financial, corporate, and commercial hub of Latin America. In addition to the differences in the realities, there was the fact that the institutions were the workplace of the study authors.

Analysis of UCPP indicated that the three institutions showed similarities regarding course length, course regimen (full-time course), and proposal of early initiation of practical activities, aiming to develop skills for professional practice in SUS. The institutions declared that the DCN/ENF guidelines were used to guide their pedagogical projects. From the strategic perspective, the UCPP of HEI-2 was based on problem-solving methodologies, whereas the UCPP of the other two institutions were grounded in a combination of traditional and active methodologies.

The inclusion criteria were: being an alumnus of an undergraduate nursing course at one of the three institutions included in the study and having completed their college training from 2013 to 2017. Incomplete filling of the instrument or nonobservance of established deadlines were considered exclusion criteria to be applied in the data organization step. All participants signed free and informed consent forms.

\section{SAMPLE}

Information about the alumni present in academic records, such as e-mail, phone, and date of graduation in the nursing course, was previously requested to the academic offices of the HEIs after presentation of the agreement letters to the respective administrative bodies. At first, selection of participants was carried out by gathering data about the students who got their degree between 2013 and 2017. There were records of 603 nursing alumni, with a distribution of 75, 187, and 341 alumni of HEI-1, HEI-2, and HEI-3, respectively. 
Sample size was calculated based on this population ( $n=603$ ) by estimating a $95 \%$ confidence interval and the level of significance obtained by using the OpenEpi ${ }^{\circledR}$ version 2 operational system ${ }^{(6)}$. It is recommended that there be at least five individuals per question in the collection instrument ${ }^{(7)}$. The used instrument, entitled Instrument for Assessment of Nursing Alumni (IAE-ENF, as per its abbreviation in English), has 87 questions, which meant that the minimum sample size would be 435 alumni $^{(8-9)}$. It is important to clarify that the present study stuck to the 85 structured questions of IAE-ENF, which allow exclusively quantitative analysis. The two semi-structured questions were not considered in the analysis because of the quantity of data they originated and because their qualitative nature requires a different structured way of presenting them.

\section{Data Collection and Instrument}

Data collection occurred between June 2017 and June 2018. The electronic link to access the evaluation instrument was sent to the alumni by e-mail together with the free and informed consent form, whose fulfillment was the first to be requested and carried out by the participants. To keep freedom of choice regarding participation in the study, the alumni could decline the invitation or withdraw their consent at any phase of the study. SurveyMonkey ${ }^{\circledR}$ online software was used to collect data.

The IAE-ENF instrument has three dimensions related to alumni characterization and insertion into the job market, evaluation of the professional training process, and assessment of professional practice. It can be used across the Brazilian territory, since it was based on $\mathrm{DCN} / \mathrm{ENF}^{(8-9)}$. The use of IAE-ENF was authorized by the researchers who designed the instrument for data collection in the present study.

\section{Data Analysis and Treatment}

After completion of the data collection step, the information was stored on SurveyMonkey ${ }^{\circledR}$ and tabulated in a Microsoft Excel ${ }^{\circledR}$ spreadsheet. As recommended by the IAE-ENF creators, a new reliability test was applied ${ }^{(8)}$, and the parameter was evaluated by calculating Cronbach's alpha. The value was 0.98 , which indicated very high reliability and pointed to an instrument with excellent internal consistency. The data obtained from the alumni of the three HEIs were analyzed and compared by using absolute numbers and percentages.

\section{EthIICAL AspeCts}

The proposal was approved by the Federal University of São Paulo Research Ethics Committee as a multicenter study as per report 0977/2016 and Certificate of Presentation for Ethical Evaluation no. 57869516.7.0000.5505.

\section{RESULTS}

Of the 446 alumni who were in the sample, $60.5 \%$ were of HEI-3, $25.7 \%$ of HEI-2, and $13.6 \%$ of HEI-1.
The sociodemographic characterization showed that $44.8 \%$ of the participants declared that they were white, followed by $38.5 \%$ who declared that they had brown skin. Women accounted for $88.6 \%$ of the sample, and $81.6 \%$ of the alumni were up to 30 years old. Completion of the undergraduate nursing course from 2013 to 2016 prevailed, accounting for $80.6 \%$ of the sample. In the HEI located in Acre, the percentage of alumni who were men (24.6\%) was substantially higher than those found for the other institutions. In HEI-2, the prevalent age group was up to 25 years old, pointing out a young profile for the undergraduate nursing course alumni of the analyzed institutions.

Table 1 shows the sociodemographic and academic characteristics of nursing alumni for each HEI included in the study. The sum shown for some variables exceeded the total number of participants $(n=446)$ because more than one answer option was offered (including the option of not answering) and the percentages were calculated by using the number of respondents as the total.

Regarding the academic path of the alumni, Table 1 showed that $34.2 \%$ of the participants opted for university extension projects and/or programs over their undergraduate course. In HEI-1, slightly more than 50\% declared to have been involved in undergraduate research and social projects and programs. In HEI-2, the search for extracurricular internships and social projects and/or programs stood out. In HEI-3, participation in academic leagues and social projects and/or programs accounted for more than $70 \%$ of the answers. Overall, considering the frequency found for each extracurricular activity category, undergraduate research was the least sought activity.

Nearly two thirds (60.7\%) of the alumni of HEI-3 had specialization, either complete or ongoing. In HEI-2 and HEI-1, these numbers were $55.7 \%$ and $21.3 \%$, respectively. Previous high-school level training in nursing did not reach $10 \%$ of the participants in any institution. Regarding employment relationship, 60\% carried out activities in one institution only, especially in HEI-3 (71.1\%). It must be emphasized that there were unemployed alumni in the nursing area: $25 \%$ of the participants, with the highest percentage found in HEI-2. This number, summed to the proportion of nurses who worked in a different area or profession, accounted for $31.9 \%$ of the sample.

Most of the alumni informed that they got their first job in the nursing area up to six months after their graduation, and this result was more prevalent in HEI-3. Regarding income, $42 \%$ of the alumni received what corresponded to between four and seven minimum wages in the data collection period, followed by $31.9 \%$ with an income from two to four minimum wages. Regarding employment relationship, $89.3 \%$ had a remunerated job, of whom $57.1 \%$ developed their activities in the healthcare area and $20.1 \%$ in the management field. Analysis of the healthcare categories showed that most alumni worked in the hospital setting, both general and specialized institutions. Taking into account the professionals who informed to work in emergency sectors, the 
Table 1 - Sociodemographic and academic characteristics of undergraduate nursing alumni of higher education institutions 1, 2, and 3. São Paulo, SP, Brazil, 2018.

\begin{tabular}{|c|c|c|c|c|}
\hline Variables & HEI-1 & HEI-2 & HEI-3 & Total \\
\hline \multicolumn{5}{|l|}{ Ethnicity } \\
\hline Yellow & $7(11.5)$ & $3(2.6)$ & $11(5.4)$ & $21(5.5)$ \\
\hline White & $6(9.8)$ & $25(21.7)$ & $139(\mathbf{6 8 . 5})$ & $170(\mathbf{4 4 . 8})$ \\
\hline Black & $5(8.2)$ & $13(11.3)$ & $18(8.8)$ & $36(9.5)$ \\
\hline Brown & $40(\mathbf{6 5 . 5})$ & $73(63.4)$ & $33(16)$ & $146(38.5)$ \\
\hline I do not wish to declare & $3(4.9)$ & $1(0.9)$ & $2(1.0)$ & $6(1.7)$ \\
\hline Did not answer & & & & $67(17.7)$ \\
\hline \multicolumn{5}{|l|}{ Gender } \\
\hline Female & $46(75.4)$ & $103(\mathbf{9 0 . 4})$ & $186(\mathbf{9 1 . 6})$ & $336(\mathbf{8 8 . 6})$ \\
\hline Male & $15(24.6)$ & $11(9.6)$ & $17(8.4)$ & $43(11.4)$ \\
\hline Did not answer & & & & $67(17.8)$ \\
\hline \multicolumn{5}{|l|}{ Age } \\
\hline Up to 25 years old & $14(22.9)$ & $47(\mathbf{4 0 . 9})$ & $94(\mathbf{3 4 . 8})$ & $155(34.7)$ \\
\hline 26 to 30 years old & $36(\mathbf{5 9 . 0})$ & 39 (33.9) & $134(\mathbf{4 9 . 6})$ & 209 (46.9) \\
\hline 31 to 35 years old & $6(9.8)$ & $14(12.2)$ & $33(12.2)$ & $53(11.9)$ \\
\hline 36 years old & $5(8.2)$ & $15(13.0)$ & $9(3.3)$ & $29(6.5)$ \\
\hline \multicolumn{5}{|l|}{ Completion year } \\
\hline 2011-2012 & $5(8.3)$ & $2(1.7)$ & $16(6.5)$ & $23(5.4)$ \\
\hline 2013-2014 & $27(\mathbf{4 5})$ & $34(29.6)$ & $96(\mathbf{3 8 . 9})$ & $157(37.2)$ \\
\hline 2015-2016 & $17(\mathbf{2 8 . 3})$ & $66(57.4)$ & $100(\mathbf{4 0 . 5})$ & $183(43.4)$ \\
\hline 2017-2018 & $11(18.3)$ & $13(11.3)$ & $35(14.2)$ & $59(14)$ \\
\hline \multicolumn{5}{|l|}{ Extracurricular activities } \\
\hline Extracurricular internship & $12(19.7)$ & $81(\mathbf{7 0 . 4})$ & $112(41.5)$ & $205(23)$ \\
\hline Undergraduate research & $31(\mathbf{5 0 . 8})$ & $50(43.5)$ & $83(30.7)$ & $164(18.4)$ \\
\hline Academic league & $11(18.0)$ & $8(7.0)$ & $199(73.7)$ & $218(24.4)$ \\
\hline University extension project and/or program & $31(\mathbf{5 0 . 8})$ & $77(67.0)$ & $197(73)$ & $305(34.2)$ \\
\hline \multicolumn{5}{|l|}{ Highest academic degree } \\
\hline Complete lato-sensu specialization & $6(9.8)$ & $34(\mathbf{2 9 . 6})$ & $100(37.0)$ & $140(31.4)$ \\
\hline Specialization training in progress & $7(11.5)$ & $30(\mathbf{2 6 . 1})$ & $64(23.7)$ & $101(22.7)$ \\
\hline $\begin{array}{c}\text { Nursing degree with a license to carry out } \\
\text { teaching activities }\end{array}$ & $1(1.64)$ & $3(2.61)$ & $6(2.22)$ & $10(2.2)$ \\
\hline Nursing degree & $47(77.0)$ & $48(41.7)$ & $100(37.0)$ & $195(43.7)$ \\
\hline \multicolumn{5}{|l|}{ Previous training } \\
\hline No & $54(\mathbf{8 8 . 5})$ & 95 (82.6) & $242(\mathbf{9 1 . 3})$ & $391(\mathbf{8 8 . 7})$ \\
\hline Yes, nursing aide & $5(8.2)$ & $3(2.6)$ & 0 & $8(1.8)$ \\
\hline Yes, nursing technician & $2(3.3)$ & $17(14.9)$ & $23(8.7)$ & $42(9.5)$ \\
\hline \multicolumn{5}{|l|}{ Job in the nursing area } \\
\hline Yes, in one institution only & $34(\mathbf{5 5 . 7})$ & $45(39.1)$ & $192(\mathbf{7 1 . 1})$ & $271(\mathbf{6 0 . 1})$ \\
\hline Yes, in more than one institution & $10(16.4)$ & $11(9.6)$ & $5(1.8)$ & $26(5.8)$ \\
\hline Yes, self-employed in nursing & $2(3.3)$ & $1(0.9)$ & $7(2.6)$ & $10(2.2)$ \\
\hline No, because I am unemployed & $11(18.0)$ & $46(\mathbf{4 0 . 0})$ & $56(20.7)$ & $113(25)$ \\
\hline No, another area/profession & $6(9.8)$ & $13(\mathbf{1 1 . 3})$ & $12(4.4)$ & $31(6.9)$ \\
\hline \multicolumn{5}{|l|}{ Time to get the job since graduation } \\
\hline Up to 6 months & 19 (38.5) & $27(42.9)$ & $142(81.6)$ & $188(65.5)$ \\
\hline From 6 months to 1 year & $17(34.9)$ & $17(27.0)$ & $21(12.1)$ & $55(19.1)$ \\
\hline From 1 to 3 years & $10(20.4)$ & $15(23.8)$ & $8(4.6)$ & $33(11.6)$ \\
\hline
\end{tabular}

continue... 


\begin{tabular}{|c|c|c|c|c|}
\hline Variables & HEI-1 & HEI-2 & HEI-3 & Total \\
\hline From 3 to 5 years & $1(2.1)$ & $2(3.2)$ & $2(1.1)$ & $5(1.7)$ \\
\hline Over 5 years & $3(6.7)$ & $2(3.2)$ & $1(0.6)$ & $6(2.1)$ \\
\hline \multicolumn{5}{|c|}{ Income (minimum wages)* } \\
\hline Up to 2 & $4(8.5)$ & $21(36.8)$ & $13(7.6)$ & $38(13.8)$ \\
\hline 2 to 4 & $13(27.7)$ & $29(\mathbf{5 1})$ & $46(26.7)$ & 88 (31.9) \\
\hline 4 to 7 & $22(\mathbf{4 6 . 8})$ & $4(7.0)$ & $90(\mathbf{5 2 . 3})$ & $116(\mathbf{4 2 . 0})$ \\
\hline 7 to 10 & $8(17.0)$ & $2(3.5)$ & $22(12.8)$ & $32(11.6)$ \\
\hline Over 10 & 0 & $1(1.7)$ & $1(0.6)$ & $2(0.7)$ \\
\hline
\end{tabular}

Results expressed as n (\%).

*The minimum wage during the study execution period was R\$954, which corresponded to US\$289.09.

HEI: higher education institution.

Table 2 - Characteristics of the professional activities developed by undergraduate nursing course alumni of higher education institutions 1, 2, and 3. São Paulo, SP, Brazil, 2018.

\begin{tabular}{|c|c|c|c|c|}
\hline Variables & HEI-1 & HEI-2 & HEI-3 & \\
\hline \multicolumn{5}{|l|}{$\begin{array}{l}\text { Professional } \\
\text { relationship }\end{array}$} \\
\hline Paid occupation & $39(\mathbf{6 3 . 0})$ & 39 (33.9) & $130(48.1)$ & $208(89.3)$ \\
\hline Self-employed & $3(4.9)$ & 0 & $4(1.5)$ & $7(3.0)$ \\
\hline Employer & $3(4.9)$ & 0 & $14(5.2)$ & $17(7.3)$ \\
\hline Consultant & $1(1.6)$ & 0 & 0 & $1(0.4)$ \\
\hline \multicolumn{5}{|l|}{ Area } \\
\hline Management & $13(21.3)$ & $26(22.6)$ & $21(7.8)$ & $60(20.1)$ \\
\hline Health care & $35(\mathbf{5 7 . 3})$ & 0 & $135(\mathbf{5 0})$ & $170(57.1)$ \\
\hline Education & $11(18)$ & 0 & $31(11.5)$ & $42(14.1)$ \\
\hline Research & $2(3.3)$ & 0 & $17(6.3)$ & $19(6.4)$ \\
\hline $\begin{array}{l}\text { Consulting and } \\
\text { advising }\end{array}$ & $1(1.6)$ & 0 & $6(2.2)$ & $7(2.3)$ \\
\hline \multicolumn{5}{|l|}{ Care modality } \\
\hline Specialty clinic & $3(4.9)$ & $6(5.2)$ & $13(4.8)$ & $22(6.7)$ \\
\hline Emergency & $7(11.4)$ & 0 & $16(5.9)$ & $23(7.1)$ \\
\hline General hospital & 25 (40.9) & 0 & $88(35.5)$ & $113(34.9)$ \\
\hline $\begin{array}{l}\text { Specialized } \\
\text { hospital }\end{array}$ & $6(9.8)$ & 0 & $40(14.8)$ & $46(14.2)$ \\
\hline $\begin{array}{l}\text { Family health } \\
\text { strategy }\end{array}$ & $4(6.5)$ & $14(12.1)$ & $17(6.3)$ & 35 (10.8) \\
\hline Basic health unit & $3(4.9)$ & $12(10.4)$ & 0 & $15(4.6)$ \\
\hline Research & $1(1.6)$ & 0 & $16(5.9)$ & $17(5.2)$ \\
\hline $\begin{array}{l}\text { Teaching (higher } \\
\text { education and } \\
\text { high school) }\end{array}$ & $8(13.1)$ & 0 & $13(4.8)$ & $21(6.5)$ \\
\hline Home nursing & $1(1.6)$ & 0 & $10(3.7)$ & $11(3.4)$ \\
\hline $\begin{array}{l}\text { Occupational } \\
\text { nursing }\end{array}$ & $1(1.6)$ & 0 & $4(1.5)$ & $5(1.5)$ \\
\hline Others & & & & $17(5.1)$ \\
\hline
\end{tabular}

Results expressed as $\mathrm{n}(\%)$.

percentage of alumni who had a job in tertiary health care was $56.2 \%$ (Table 2 ).

The results of dimensions 2 and 3 of IAE-ENF, which addressed the perception of alumni regarding academic training and professional practice experienced by them, respectively, are shown in Tables 3 and 4. It must be emphasized that the alumni who did not answer the questions were not included in the calculations in these dimensions of the instrument. The answer options of the seven questions that made up this dimension were presented as a semantic differential scale, and the authors opted to keep the wording used in each question to interpret the results more accurately. Table 3 shows the results of questions that are part of dimension 2 of IAE-ENF, indicating marked differences between the three HEIs.

Table 3 indicates that the sum of the numbers obtained for positive descriptors ("I totally agree" and "I agree") exceeded 50\% in HEI-2 and HEI-3. The results demonstrated that the evaluation of alumni of HEI-1 was that their undergraduate course did not satisfactorily fulfill its role regarding development of skills in the following areas: health care; health education and management, in line with care level and regional specificities; ethical and bioethical principles; and competencies to manage and/or apply technical and scientific knowledge. Table 4 shows the alumni's perception regarding professional practice.

The alumni of HEI-2 and HEI-3 were divided into those who considered the professional preparation obtained in practical activities and internships as medium or sufficient. The alumni of HEI-1 classified their remuneration from medium to sufficient. The participants who got their degree in HEI-2 declared that their payment was between insufficient and totally insufficient. The alumni of HEI-3 answered that their remuneration was from medium to insufficient. Regarding evaluation processes adopted in the examined undergraduate courses, the alumni of HEI- 2 and HEI-3 declared that their quality ranged from medium to adequate, whereas most alumni of HEI-1 reported that these processes were adequate. When the alumni were asked about perception regarding skills acquired over their undergraduate course and demands of the work world, the professionals who studied at HEI-1 reported a more positive perception than the alumni of the other institutions, including feeling happy about being a nurse and their professional practice, as well as their overall evaluation. 
Table 3 - Skills acquired during academic training present in dimension 2 of IAE-ENF according to the alumni. São Paulo, SP, Brazil, 2018.

\begin{tabular}{|c|c|c|c|c|c|}
\hline Skills & Scale & HEI-1 & HEI-2 & HEI-3 & Total \\
\hline \multirow{5}{*}{$\begin{array}{l}\text { Taking responsibility for } \\
\text { quality of nursing care in its } \\
\text { different care levels }\end{array}$} & I totally agree & $18(29.5)$ & $36(\mathbf{3 1 . 3})$ & $113(\mathbf{4 1 . 9})$ & $167(37.4)$ \\
\hline & I agree & $9(14.8)$ & $49(\mathbf{4 2 . 6})$ & $75(\mathbf{2 7 . 8})$ & $133(29.8)$ \\
\hline & I neither agree nor disagree & $3(4.9)$ & $20(17.4)$ & $40(14.8)$ & $63(14.1)$ \\
\hline & I disagree & $31(\mathbf{5 0 . 8})$ & $5(4.3)$ & $22(8.1)$ & $58(13.1)$ \\
\hline & I totally disagree & 0 & $5(4.3)$ & $20(7.4)$ & $25(5.6)$ \\
\hline \multirow{5}{*}{$\begin{array}{l}\text { Meeting regional health } \\
\text { specificities by means of } \\
\text { planned interventions }\end{array}$} & I totally agree & $14(23.0)$ & $26(\mathbf{2 2 . 6})$ & $76(\mathbf{2 8 . 1})$ & $116(26.0)$ \\
\hline & I agree & $9(14.8)$ & $53(\mathbf{4 6 . 1})$ & $86(31.9)$ & $148(33.2)$ \\
\hline & I neither agree nor disagree & $4(6.6)$ & $24(20.9)$ & $62(23.0)$ & $90(20.2)$ \\
\hline & I disagree & $32(\mathbf{5 2 . 5})$ & $9(7.8)$ & $31(11.5)$ & $72(16.1)$ \\
\hline & I totally disagree & $2(3.3)$ & $3(2.6)$ & $15(5.6)$ & $20(4.5)$ \\
\hline \multirow{5}{*}{$\begin{array}{l}\text { Managing the work process } \\
\text { with ethical and bioethical } \\
\text { principles }\end{array}$} & I totally agree & $16(26.2)$ & $53(\mathbf{4 6 . 1})$ & $114(\mathbf{4 2 . 2})$ & $183(41.0)$ \\
\hline & I agree & $10(16.4)$ & $38(\mathbf{3 3 . 0})$ & $72(\mathbf{2 6 . 7})$ & $120(26.9)$ \\
\hline & I neither agree nor disagree & $3(4.9)$ & $14(12.2)$ & $51(18.9)$ & $68(15.3)$ \\
\hline & I disagree & $31(\mathbf{5 0 . 8})$ & $4(3.5)$ & $16(5.9)$ & $51(11.4)$ \\
\hline & I totally disagree & $1(1.6)$ & $6(5.2)$ & $17(6.3)$ & $24(5.4)$ \\
\hline \multirow{5}{*}{$\begin{array}{l}\text { Planning, implementing, and } \\
\text { evaluating health education } \\
\text { programs }\end{array}$} & I totally agree & $12(19.7)$ & $43(37.4)$ & $65(\mathbf{2 4 . 1})$ & $120(26.9)$ \\
\hline & I agree & $14(23.0)$ & $48(\mathbf{4 1 . 7 )}$ & $102(\mathbf{3 7 . 8})$ & $164(36.8)$ \\
\hline & I neither agree nor disagree & $2(3.3)$ & $17(14.8)$ & $68(25.2)$ & $87(19.5)$ \\
\hline & I disagree & $31(\mathbf{5 0 . 8})$ & $4(3.5)$ & $28(10.4)$ & $63(14.1)$ \\
\hline & I totally disagree & $2(3.3)$ & $3(2.6)$ & $7(2.6)$ & $12(2.7)$ \\
\hline \multirow{5}{*}{$\begin{array}{l}\text { Producing technical and } \\
\text { scientific knowledge and } \\
\text { making it collective }\end{array}$} & I totally agree & $14(23.0)$ & $30(26.1)$ & $93(34.7)$ & $137(30.9)$ \\
\hline & I agree & $7(11.5)$ & $49(42.6)$ & $83(31.0)$ & $139(31.3)$ \\
\hline & I neither agree nor disagree & $6(9.8)$ & $26(22.6)$ & $55(20.5)$ & $87(19.5)$ \\
\hline & I disagree & $32(52.5)$ & $6(5.2)$ & $16(6.0)$ & $54(12.2)$ \\
\hline & I totally disagree & $2(3.3)$ & $4(3.5)$ & $21(7.8)$ & $27(6.1)$ \\
\hline
\end{tabular}

Results expressed as n (\%).

$\mathrm{HEI}$ : higher education institution.

Table 4 - Evaluation of professional practice according to dimension 3 of IAE-ENF according to the alumni. São Paulo, SP, Brazil, 2018.

\begin{tabular}{|c|c|c|c|c|c|}
\hline \multicolumn{2}{|c|}{ Dimension 3} & \multirow{2}{*}{ HEI-1 } & \multirow{2}{*}{ HEI-2 } & \multirow{2}{*}{ HEI-3 } & \multirow{2}{*}{ All } \\
\hline Questions & Answers & & & & \\
\hline \multirow{5}{*}{$\begin{array}{l}\text { Relationship between } \\
\text { academic training and } \\
\text { demands experienced in the } \\
\text { job market }\end{array}$} & Unqualified & $1(1.7)$ & $5(4.3)$ & $7(2.6)$ & $13(2.9)$ \\
\hline & Little qualified & 0 & $9(7.8)$ & $9(3.3)$ & $18(4.1)$ \\
\hline & Medium & $8(13.8)$ & $56(\mathbf{4 8 . 7})$ & $84(31.1)$ & $148(33.4)$ \\
\hline & Qualified & $46(79.3)$ & $37(32.2)$ & $104(\mathbf{3 8 . 5})$ & $187(42.2)$ \\
\hline & Very qualified & $3(5.2)$ & $8(7.0)$ & $66(\mathbf{2 4 . 4})$ & $77(17.4)$ \\
\hline \multirow{5}{*}{$\begin{array}{l}\text { Relationship between } \\
\text { practical content (practical } \\
\text { activities and internships) } \\
\text { and preparation for } \\
\text { professional practice }\end{array}$} & Very insufficient & 0 & $3(2.6)$ & $4(1.5)$ & $7(1.6)$ \\
\hline & Insufficient & $4(6.6)$ & $9(7.8)$ & $26(9.6)$ & $39(8.7)$ \\
\hline & Medium & $11(18.0)$ & 49 (42.6) & $118(\mathbf{4 3 . 7 )}$ & $178(39.9)$ \\
\hline & Sufficient & $38(62.3)$ & $40(\mathbf{3 4 . 8})$ & $75(\mathbf{2 7 . 8})$ & $153(34.3)$ \\
\hline & Very sufficient & $8(13.1)$ & $14(12.2)$ & $47(17.4)$ & $69(15.5)$ \\
\hline \multirow{5}{*}{$\begin{array}{l}\text { How do you classify } \\
\text { remuneration in nursing? }\end{array}$} & Very insufficient & $11(18.0)$ & $43(\mathbf{3 7 . 4})$ & $19(7.0)$ & $73(16.4)$ \\
\hline & Insufficient & $10(16.4)$ & $27(\mathbf{2 3 . 5})$ & $49(\mathbf{1 8 . 1})$ & $86(19.3)$ \\
\hline & Medium & $13(\mathbf{2 1 . 3})$ & $35(30.4)$ & $158(\mathbf{5 8 . 5})$ & $206(46.2)$ \\
\hline & Sufficient & $27(\mathbf{4 4 . 3})$ & $8(7.0)$ & $42(15.6)$ & $77(17.2)$ \\
\hline & Very sufficient & 0 & $2(1.7)$ & $2(0.7)$ & $4(0.9)$ \\
\hline
\end{tabular}

continue... 


\begin{tabular}{|c|c|c|c|c|c|}
\hline \multicolumn{2}{|c|}{ Dimension 3} & \multirow{2}{*}{ HEI-1 } & \multirow{2}{*}{ HEI-2 } & \multirow{2}{*}{ HEI-3 } & \multirow{2}{*}{ All } \\
\hline Questions & Answers & & & & \\
\hline \multirow{5}{*}{$\begin{array}{l}\text { Perception regarding the } \\
\text { type of evaluation adopted } \\
\text { in the teaching-learning } \\
\text { process }\end{array}$} & Inadequate & $1(1.6)$ & $6(5.3)$ & $3(1.1)$ & $10(2.2)$ \\
\hline & Little adequate & 0 & $11(9.6)$ & $22(8.1)$ & $33(7.4)$ \\
\hline & Medium & $18(29.5)$ & $54(\mathbf{4 7 . 4})$ & $133(\mathbf{4 9 . 3 )}$ & $205(46.1)$ \\
\hline & Adequate & $38(\mathbf{6 2 . 3})$ & $33(\mathbf{2 8 . 9})$ & $81(\mathbf{3 0 . 0})$ & $152(34.2)$ \\
\hline & Very adequate & $4(6.6)$ & $10(8.8)$ & $31(11.5)$ & $45(10.1)$ \\
\hline \multirow{5}{*}{$\begin{array}{c}\text { Are you happy with the } \\
\text { professional activities you } \\
\text { carry out in the nursing } \\
\text { area? }\end{array}$} & Not happy & 0 & $10(8.7)$ & $8(3.0)$ & $18(4.1)$ \\
\hline & Little happy & $3(4.9)$ & $11(9.6)$ & $39(14.4)$ & $53(11.9)$ \\
\hline & Medium & 18 (29.5) & $50(\mathbf{4 3 . 5})$ & $135(\mathbf{5 0 . 0})$ & $203(45.5)$ \\
\hline & Happy & $37(\mathbf{6 0 . 7})$ & $31(\mathbf{2 7 . 0})$ & $69(25.6)$ & 137 (30.7) \\
\hline & Very happy & $3(4.9)$ & $13(11.3)$ & $19(7.0)$ & $35(7.8)$ \\
\hline \multirow{5}{*}{$\begin{array}{c}\text { Are you happy about being } \\
\text { a nurse? }\end{array}$} & Not happy & $1(1.6)$ & $3(2.6)$ & $7(2.6)$ & $11(2.5)$ \\
\hline & Little happy & $1(1.6)$ & $15(13.0)$ & $30(11.1)$ & $46(10.3)$ \\
\hline & Medium & $14(23.0)$ & $42(\mathbf{3 6 . 5})$ & 119 (44.1) & $175(39.2)$ \\
\hline & Happy & $37(\mathbf{6 0 . 7})$ & $36(\mathbf{3 1 . 3})$ & $74(\mathbf{2 7 . 4})$ & $147(33.0)$ \\
\hline & Very happy & $8(13.1)$ & $19(16.5)$ & $40(14.8)$ & $67(15.0)$ \\
\hline \multirow{5}{*}{$\begin{array}{l}\text { How do you evaluate your } \\
\text { undergraduate nursing } \\
\text { course? }\end{array}$} & Inadequate & 0 & $2(1.7)$ & $5(1.9)$ & $7(1.6)$ \\
\hline & Little adequate & $1(1.6)$ & $6(5.2)$ & $18(6.7)$ & $25(5.5)$ \\
\hline & Medium & $10(16.4)$ & 49 (42.6) & $89(33.0)$ & $148(33.2)$ \\
\hline & Adequate & $44(72.1)$ & $42(\mathbf{3 6 . 5})$ & 95 (35.2) & $181(40.6)$ \\
\hline & Very adequate & $6(9.8)$ & 16 (13.9) & $63(\mathbf{2 3 . 3})$ & $85(19.1)$ \\
\hline
\end{tabular}

Results expressed as n (\%).

$\mathrm{HEI}$ : higher education institution.

\section{DISCUSSION}

The HEIs included in the present study are located in the North and Southeast Regions of Brazil and are geographically distant, given the continental dimensions of the country. However, it was found that the socioeconomic profiles of the alumni of the three study settings were similar. Most alumni declared themselves white in HEI- 3 and brown in HEI-1 and HEI-2, and were women up to 30 years old in the three institutions. These findings corroborated the results of other studies that have reported similar alumni profiles ${ }^{(9-10)}$.

Regarding gender, the final report of the study on the nursing profile in Brazil ${ }^{(11-12)}$, published in 2017, indicated that feminization is common in all professions in the health sector. Nursing follows and reinforces this process, since the last computed percentage of women was $86.2 \%$. The participation of men in the area is still incipient, but the presence of over 55 thousand men (13.4\%) has been recorded, indicating that their prevalence in the category is growing, as observed in the numbers for HEI-1. Still regarding comparison of the findings of the present study and official numbers, most of the workforce in nurse in Brazil, which accounts for more than 276 thousand workers, is up to 40 years old, which means that Brazilian nursing teams are predominantly young, as illustrated by the examined sample ${ }^{(11-12)}$.

Regarding academic path, the percentages showed satisfactory engagement of the alumni with choosing and participating in learning activities in an independent and self-managed way. It must be stressed that the selected HEIs are public, with tradition in education, research, and extension. Extracurricular activities, including participation in social projects, internships, and undergraduate research, among others, promote important opportunities for students to learn and receive critical, creative, and resolutive education, which is fundamental for them to be inserted into the career and might even make a difference in selection processes ${ }^{(13-14)}$.

The participation of the alumni in the undergraduate academic research sphere, however, was unsatisfactory, considering that the highest percentage, recorded for HEI-1, was $50 \%$. The experience provided by undergraduate research programs favors training of professionals so they are prepared for the challenges posed by the job market and may encourage students to follow the graduate course path. This coordination promotes visibility, recognition, and consolidation of nursing as a science ${ }^{(13-14)}$.

The three HEIs stood out in the university extension field, but it should be noted that inclusion of university extension in curricula is provided for in the Brazilian National Education Plan for the period from 2014 to 2024 as a mandatory goal of allocation of $10 \%$ of extracurricular activities in the total credits of the study program in all undergraduate courses ${ }^{(15)}$. This will be a great challenge for courses in the health area. A recent study sought to characterize, by means of a literature review, which extension conceptions are included in the Brazilian legislation. It pointed out that extension must be understood as a public policy, which dialogues with society, 
although it is a recent subject that still lacks full recognition, despite its well-outlined constitutive bases ${ }^{(16)}$.

Most alumni of HEI-2 and HEI-3 already had a specialization degree or were studying to get one, a reality different from that found for HEI-1, in which only $21 \%$ of the alumni reported having some sort of qualification beyond college degree. This can be explained by the fact that the offer of graduate courses is lower in the North Region of Brazil. This result indicates the need to speed up the creation and implementation of educational policies related to specialization courses and conventional graduate lato and stricto sensu courses that aim to minimize this difference by means of, among other strategies, research groups that have the mission of bringing together the technical and scientific realities of great urban centers and remote geographic areas that are more disadvantaged regarding possibilities of professional development ${ }^{(12,14)}$.

The results found in the present study regarding complementary training are similar to those reported in other studies carried out in different Brazilian contexts and showed, in general, that the alumni recognized that the knowledge acquired during the undergraduate course was not enough ${ }^{(17-19)}$. It is perceived that continuing education, professional training, the offer of courses, and professional updating by employing and training institutions become indispensable for nurses to develop their activities with excellence and play their role in health services in a committed and transformative way, making delivered care close to the intended pattern ${ }^{(18-19)}$.

Few alumni consulted in the present study had previous high school-level training (nursing aide and/or nursing technician courses), probably because of the difficulty getting a place in the selection processes that are characteristic of Brazilian public universities and being a student in a fulltime course, which reduces the chances of keeping a job. Conversely, the results of a study on the profile of nursing professionals showed that over $80 \%$ of the nurses working in Brazil declared that they had previous high school-level training in nursing ${ }^{(11)}$. This disparity results from the marked increase in the number of private HEIs that offer part-time nursing courses in the past two decades, despite the fulfillment of the full course load in five years ${ }^{(12)}$.

Regarding characteristics related to employability, the present study and previous ones have indicated that, most times, nurses develop their professional activities in a single institution only ${ }^{(18-19)}$. The report of the study that sought to obtain the profile of nursing professionals pointed that over half the nurses (58\%) across Brazil declared that they had only one employment relationship ${ }^{(11)}$. This piece of data may reflect the lack of jobs in nursing as well as wage disparities, which range between the offer of decent and outrageous salaries. The latter causes professionals to have more than one employment bond to make up their monthly income. It must be emphasized that, in the present study, one fourth of the alumni declared to be unemployed during the data collection period, especially in HEI-2. This finding, combined with the number of nurses who worked in another area or profession, is worrisome. In Brazil, the percentage of self-reported unemployment among nurses over the past 12 months is $12.4 \%$, a number that accounts for over 51 thousand professionals. Of this total, $78.9 \%$ reported having difficulty finding a job, especially in places far from state capitals ${ }^{(11-12)}$.

Regarding time to get the first job, previous studies have reported results similar to those found in the present one, indicating a period of up to six months for entering the job market after graduation ${ }^{(10,17-19)}$. In a study carried out in a municipality in the interior of the state of São Paulo(19), although most participants were employed, there were accounts of difficulty to enter the job market, which again corroborates the conclusion that capitals concentrate job vacancies. An example of this fact was the difficulty to get a job reported by the alumni of HEI-2, located in a city far from the capital of the state of Minas Gerais. This centralization has several consequences, including lack of resources in the health area for the populations living in the interior of Brazilian states and continuous geographic commutes. Both can negatively impact patient survival rates and family health, especially in people who depend on SUS ${ }^{(4-5)}$.

The classification of the main difficulties mentioned in nurse employability showed: lack of professional experience; little offer of part-time jobs; lack of public tenders; few opportunities in the specialization area; little information about job vacancies; low salaries; few employee benefits; work overload; low level of appeal for geographical areas that are difficult to reach; and dissatisfaction with professional practice, among others ${ }^{(5,12,17)}$. These reasons allow to infer that entering the job market can be a stressful experience that goes against the expectations of alumni, who, faced with the reduced job offer and the need to have an income, initiate their career opposing their vocational wishes, as illustrated by the results of the present study. When asked about their satisfaction with their professional activities in the nursing area, most participants provided answers that ranged between not happy and moderately happy.

The remuneration of the alumni consulted in the present study ranged from two to 10 minimum wages (during the data collection period, the minimum wage in Brazil was $\mathrm{R} \$ 954$, which corresponded to US\$289.09), which indicated a wide range in monthly income that does not bring motivational benefits for nurses to stay in the profession. A study in Israel oriented toward finding the perceptions of undergraduate nursing course students regarding insertion of men into the job market, motivation to choose the profession, and the social status assigned to it identified negative factors, such as: gender differences and stereotypes that work against men's choosing of the profession; social perception of the profession as being of a lower rank; choice guided by ideology; low remuneration; precarious working conditions; and work overload, which leads to professional burnout ${ }^{(20)}$.

Regarding the area in which the alumni developed their activities, most participants worked in the healthcare area, and the hospital setting stood out, whether the institution was general or specialized, a finding that was similar to those reported in other studies ${ }^{(10,17-20)}$. The practice of healthcare activities at the beginning of the career is appropriate because it provides a greater theoretical and scientific improvement 
in the development of basic skills for the initial practice in the profession ${ }^{(10,19)}$. Greater employability in the hospital setting can be justified by sizing (at least four nurses are required per sector, because of the continuous shift work dynamics) and the presence of higher complexity units, such as emergency rooms and intensive care units, which demand a higher number of nurses.

Although these explanations are plausible, low employability in primary and secondary health care of the participants is worrisome and calls for reflections on, at least, two possibilities of analysis: the fact that UCPP still value hospital-centered education and the pressing need for HEIs to mobilize themselves socially to promote employability in primary health care. Both options pose great challenges. It is noteworthy that these findings are in the opposite direction of what is advocated as measures to strengthen SUS public policies for all age groups, since these encourage gradual investments in health prevention and promotion so, in the next decades, the Brazilian society can reduce its alarming rates of acute and chronic diseases. The same ideas pervade DCN/ENF themselves, given that SUS must be the scenario of professional training ${ }^{(3-4)}$.

Evaluating the training received by the alumni by analyzing the data collected with the application of dimension 2 of IAE-ENF originated important information for reflection on professional training considering the skill keystones contained in DCN/ENF: care, management, education, and research ${ }^{(3)}$. The set of data analyzed in dimensions 2 and 3 showed that the alumni of HEI- 2 and HEI- 3 recognized that undergraduate courses offer construction of competences over the training trajectory.

The alumni of HEI-3, located in the Brazilian state capital with the greatest offer of health services, showed better performance regarding employability and time to get the first job after graduation and reported higher wage ranges. Taking into account that measuring the quality of professional training of nurses by evaluating alumni is an indirect evaluation that uses indicators commonly applied in the specialized literature, such as those that make up dimensions 2 and 3 of IAE-ENF ${ }^{(8-9)}$, it is possible to infer, from comparative data analysis, that the UCPP of HEI-2 and HEI-3 follow DCN/ENF more concretely and strikingly.

Although the alumni of HEI-1 negatively evaluated their training regarding learning of fundamental skills, there was a greater share of them who were happy with the situation in the job market and the adequacy of the received training to the demands of professional practice in comparison with the numbers obtained for the universities located in São Paulo and Montes Claros. Regarding dissatisfaction of alumni of HEI-2 and HEI-3, there is the need to analyze the phenomenon from the perspective of professional practice incompatibility, originating from the shaping of the job market into little preparation or flexibility to take advantage of alumni's skills and the little flexibility in the training of the students itself, who turn out not being ready to deal with self-managed decisions and progresses in the corporate world. From both perspectives, making the relationships between educational and employing institutions closer could favor modernizing and harmonizing changes in both and cause social, technical, and ethical values to be realigned ${ }^{(21)}$.

It is advised that the reliability of IAE-ENF be tested again before application to populations of alumni with characteristics that differ from those of the participants of the present multicenter study. It is recommended to replace the word "sex" with "gender" in the sociodemographic section of the instrument and to include gender alternatives and/or an alternative with the wording "I do not wish to declare my gender". Regarding sample size, it is suggested that the difficulty finding respondents and the fact that completion of the instrument takes up to 30 minutes on average are taken into account. Therefore, the authors recommend considering strategies that allow auto-saving or sending the answers afterward, in case of personal contact. It is important to stress that the decision of not presenting the collected qualitative data excluded important analyses.

\section{IMPLICATIONS FOR PRACTICE}

Evaluating alumni by applying a structured and validated instrument based on current guidelines brought important information to the process of continuing assessment of the examined undergraduate courses and allowed making comparisons between distinct geographic areas, providing critical-reflective analysis of UCPP, both in isolation and in combination.

\section{CONCLUSION}

The sociodemographic profiles of the alumni of the three chosen HEIs showed similarities regarding the prevalence of women and young people. In dimension 1 of IAE-ENF, the employability rate was high up to six months after graduation. Most participants reported an income higher than four minimum wages, which was considered below the desired level. Additionally, most consulted alumni in the Southeast Region of Brazil had further training in the form of specialization courses.

In dimension 2 of IAE-ENF, the alumni of HEI-2 and HEI-3 indicated that the curricula of their courses were strongly aligned with the contents and principles of DCN/ ENF. The alumni of HEI-1 evaluated their undergraduate nursing course as insufficient in all examined items. However, application of dimension 3 of the instrument showed that there was a greater proportion of satisfied alumni in this institution than in HEI-2 and HEI-3 regarding the situation of the job market and evaluation of the adequacy of training to demands of professional practice.

\section{RESUMO}

Objetivos: Comparar avaliações obtidas de egressos de cursos de graduação em enfermagem em três dimensões: caracterização sociodemográfica, identificação e inserção no mercado de trabalho e avaliação da formação profissional. Método: Estudo transversal, quantitativo, multicêntrico, com egressos de três universidades públicas brasileiras. A análise de dados foi feita segundo a confiabilidade interna do instrumento utilizado e por estatística descritiva. Resultados: Participaram do estudo 446 egressos concluintes entre 2013 
e 2016. A maioria era do sexo feminino, da etnia branca (44\%) e parda (38\%) e tinha entre 25 e 30 anos. A maior parte apresentou titulação lato sensu concluída ou em curso (54\%), 89\% eram assalariados, e 60\% eram empregados em única instituição, sendo prevalente a área assistencial (57\%). Verificaram-se elevados níveis de satisfação entre egressos de duas instituições na avaliação de aprendizado dos conteúdos e experiências essenciais para a formação e melhores avaliações sobre a prática profissional em outra. Conclusão: $\mathrm{O}$ perfil de experiências acadêmicas, pós-graduação e de ingresso no mercado de trabalho foi diversificado entre as instituições avaliadas. Os achados favorecem a análise crítico-reflexiva dos projetos pedagógicos.

\section{DESCRITORES}

Avaliação em Enfermagem; Estudo Multicêntrico; Educação em Enfermagem.

\section{RESUMEN}

Objetivos: Comparar evaluaciones de alumnos egresados de carreras de grado en enfermería en tres dimensiones: caracterización sociodemográfica, identificación e inserción en el mercado laboral y evaluación de la formación profesional. Método: Estudio transversal, cuantitativo, multicéntrico, con alumnos avanzados de tres universidades públicas brasileñas. Datos analizados por confiabilidad interna del instrumento utilizado y por estadística descriptiva. Resultados: Participaron 446 egresados recibidos entre 2013 y 2016 . La mayoría, de sexo femenino, etnia blanca (44\%) y mulata (38\%), franja etaria entre 25 y 30 años. La mayor parte contaba con posgrados lato sensu concluida o en curso (54\%); el 89\% eran asalariados, $60 \%$ empleados en una única institución, prevaleciendo el área asistencial (57\%). Se verificaron elevados niveles de satisfacción entre egresados de dos instituciones en la evaluación de aprendizaje de contenidos y experiencias esenciales para la formación, y mejores evaluaciones sobre la práctica profesional en otra. Conclusión: El perfil de experiencias universitarias, posgrado y de ingreso al mercado laboral fue diverso entre las instituciones evaluadas. Los hallazgos favorecen el análisis crítico-reflexivo de los proyectos pedagógicos.

\section{DESCRIPTORES}

Evaluación en Enfermería; Estudio Multicéntrico; Educación en Enfermería.

\section{REFERENCES}

1. Lima LA, Andriola WB. Acompanhamento de egressos: subsídios para a avaliação de Instituições de Ensino Superior (IES). Avaliação (Campinas). 2018;23(1):104-25. DOI: https://doi.org/10.1590/s1414-40772018000100007

2. Porto C, Régnier K. O ensino superior no mundo e no Brasil - condicionantes, tendências e cenários para o horizonte 2003-2025. Uma abordagem exploratória [Internet]. Brasília: Ministério da Educação; 2003 [cited 2021 May 14]. Available from: http://portal.mec.gov. br/sesu/arquivos/pdf/ensinosuperiormundobrasiltendenciascenarios2003-2025.pdf

3. Brasil. Ministério da Educação. Resolução CNE/CES n 3, de 7/11/2001. Institui Diretrizes curriculares nacionais do curso de graduação em enfermagem [Internet]. Brasília: Diário Oficial da União; 2001 [cited 2021 May 14]. Available from: http://www.cofen.gov.br/ resoluo-cne-ces-n-3-de-7-de-novembro-de-2001-diretrizes-nacionais-curso-graduaao-enfermagem_6933.html

4. Machado MH, Ximenes Neto FR. The management of work and education in Brazil's Unified Health System: thirty years of progress and challenges. Cien Saude Colet. 2018;23(6):1971-9. DOI: https://doi.org/10.1590/1413-81232018236.06682018

5. Winters JRF, Do Prado ML, Heidemann IT. Nursing education oriented to the principles of the Unified Health System: perception of graduates. Escola Anna Nery. 2016;20(2):248-53. DOI: https://doi.org/10.5935/1414-8145.20160033

6. Sullivan KM, Dean A, Soe MM. OpenEpi: a web-based epidemiologic and statistical calculator for public health. Public Health Rep. 2009;124(3):471-4. DOI: https://doi.org/10.1177/003335490912400320

7. Streiner DL. Figuring out factors: the use and misuse of factor analysis. Can J Psychiatry. 1994;39(3):135-40. DOI: https://doi. org/10.1177/070674379403900303

8. Vieira MA, Ohara CV, De Domenico EB. The construction and validation of an instrument for the assessment of graduates of undergraduate nursing courses. Rev Lat Am Enferm. 2016;24:e2710. DOI: http://dx.doi.org/10.1590/1518-8345.0834.2710

9. Aguiar KLA, Vieira MA, De Domenico EBL. Validação externa do instrumento de avaliação de egressos de enfermagem IAE-ENF: estudo multicêntrico [resumo 101]. In: $3^{\circ}$ Fórum Internacional de Enfermagem e $4^{\circ}$ Fórum Nacional de Enfermagem [Internet]; 2019 Nov 2528; São Paulo. São Paulo: Universidade Federal de São Paulo; 2020 [cited 2020 Oct 28]. p. 22. Available from: https://acta-ape.org/ wp-content/uploads/2020/04/Forum-Internacional-resumos.pdf

10. Barbosa AC, Luiz FS, Friedrich DB, Püschel VA, Farah BF, Carbogim FC. Profile of nursing graduates: competencies and professional insertion. Rev Lat Am Enferm. 2019;27:e3205. DOI: https://doi.org/10.1590/1518-8345.3222.3205

11. Machado $\mathrm{MH}$, Wermelinger M, Vieira M, Oliveira E, Lemos W, Aguiar Filho W, et al. Aspectos gerais da formação da enfermagem: o perfil da formação dos enfermeiros técnicos e auxiliares. Enferm Foco. 2016;7(n. esp)15-34. DOI: https://doi.org/10.21675/2357707X.2016.v7.nESP.687

12. Silva MC, Machado MH. Sistema de Saúde e Trabalho: desafios para a Enfermagem no Brasil. Ciênc Saúde Coletiva. 2020;25(1):7-13. DOI: http://dx.doi.org/10.1590/1413-81232020251.27572019

13. Silva IR, Leite JL, Trevizan MA, Silva TP, José SA. Connections between research and health care assistance: emerging challenges for science, innovation and technology in nursing. Texto Contexto Enferm. 2017;26(4):e2470016. DOI: http://dx.doi.org/10.1590/010407072017002470016

14. Erdmann AL, Peiter CC, Lanzoni GM. Grupos de pesquisa em enfermagem no Brasil: comparação dos perfis de 2006 e 2016 . Rev Gaúcha Enferm. 2017;38(2):e69051. DOI: https://doi.org/10.1590/1983-1447.2017.02.69051

15. Brasil. Ministério da Educação. Resolução $n^{\circ}$ 7, de 18 de dezembro de 2018. Estabelece as diretrizes para a extensão na educação superior brasileira e regimenta o disposto na meta 12.7 da Lei no 13.005/2014, que aprova o Plano Nacional de Educação - PNE 20142024 e dá outras providências [Internet]. Brasília: Diário Oficial da União, 2018 [cited 2021 May 14]. Available from: https://www. in.gov.br/materia/-/asset_publisher/Kujrw0TZC2Mb/content/id/55877808 
16. Albrecht E, Bastos AS. Extensão e sociedade: diálogos necessários. Revista em Extensão. 2020;19(1):54-71. DOI: https://doi.org/10.14393/ REE-v19n12020-53428

17. Püschel VA, Inácio MP, Pucci PP. Insertion of USP nursing graduates into the job market: facilities and difficulties. Rev Esc Enferm USP [Internet]. 2009 [cited 2021 May 14];43(3):534-41. Available from: https://www.scielo.br/pdf/reeusp/v43n3/en_a06v43n3.pdf

18. Püschel VA, Costa D, Reis PP, Oliveira LB, Carbogim FC. Nurses in the labor market: professional insertion, competencies and skills. Rev Bras Enferm. 2017;70(6):1220-6. DOI: https://doi.org/10.1590/0034-7167-2016-0061

19. Leal LA, Soares MI, Silva BR, Bernardes A, Camelo SH. Clinical and management skills for hospital nurses: perspective of nursing university students. Rev Bras Enferm. 2018;71(Suppl 4):1514-21. DOI: http://dx.doi.org/10.1590/0034-7167-2017-0452

20. Ashkenazi L, Livshiz-Riven I, Romem P, Grinstein-Cohen O. Male nurses in Israel: barriers, motivation, and how they are perceived by nursing students. J Prof Nurs. 2017;33(2):162-9. DOI: http://dx.doi.org/10.1016/j.profnurs.2016.08.001

21. Jackson D, Bridgstock R. Evidencing student success in the contemporary world-of-work: renewing our thinking. Higher Educ Res Dev. 2018;37(5):984-98. DOI: http://doi.org/10.1080/07294360.2018.1469603 